\title{
History and Specificity of Literary Activity of Indigenous Peoples
}

\author{
Anastasia V. Kistova* and Natalia N. Pimenova* \\ Siberian Federal University \\ 79 Svobodny, Krasnoyarsk, 660041, Russia
}

Received 12.03.2016, received in revised form 15.05.2016, accepted 27.07.2016

\begin{abstract}
The present work is a review of the main stages in the development of literary activity of the indigenous peoples of the North, Siberia, and the Far East, describing its key peculiarities. It reveals the specificity of poetry and prose. It outlines several different points of view on the concept and character of the indigenous peoples' creative activities as an ethnocultural phenomenon.

The authors arrive at the conclusion on the specific ethnic features of the literary activity of the indigenous peoples, which may be regarded as one of the efficient ways of constructing ethnocultural and national identity in the modern world.
\end{abstract}

Keywords: Literature, prose, poetry, indigenous peoples, North, Siberia, Far East.

The article was written as a part of the research under the grant of the Regional Fund for Science and Technical Activity Support for "Creation of a Corpus of Texts in National Languages (Evenki, Nenets, Nganasan, Dolgan) for Children as a Way of Preserving the Unique Cultural Heritage of the SmallNumbered Indigenous Peoples of Krasnoyarsk Region".

DOI: 10.17516/1997-1370-2016-9-9-1932-1944.

Research area: theory and history of culture.

\section{Introduction}

The oral form of literature of the indigenous peoples of the North, Siberia and the Far East have been attracting a lot of attention in Russia since the $18^{\text {th }}$ century. Written literature of the indigenous peoples has been studied since its emergence at the turn of the $19^{\text {th }}-20^{\text {th }}$ centuries. Researchers are especially interested in the modern stage of the literature development which falls on the post-Soviet period of history. It was the time of a great leap in creative writing and new conceptual attempts to apprehend the phenomenon, as noticed by M.A. Kolesnik (Kolesnik, 2014; Reznikova, 2016), A.V. Vaschenko (Vaschenko, 2002), O.K. Lagunova (Lagunova, 2011; Lagunova, 2007), E.A. Kalenchuk, A.R. Banschikova (Kalenchuk, 2015), L.I. Bakhteeva (Bakhteeva, 2008), N.A. Lopulenko (Lopulenko, 2002) etc. Specificity of creative writing of the indigenous peoples is actively studied by some foreign researchers (Heiss, 2014; Driskill, 2011; Knudsen, 2004; Allen, 2002; Heiss, 2003; Shoemaker, 2004).

And even though the main features of literature of the indigenous peoples of the North,

(c) Siberian Federal University. All rights reserved

* Corresponding author E-mail address: kistochka7@mail.ru; usataya@yandex.ru 
Siberia, and the Far East have been well studied from the point of view of philology, literary criticism and ethnopedagogy (Semenova, 2011; Burkov, 2012; Sangi, 1989; Rogacheva, 2003; Poshataeva, 1988; Popov, 2001; Nemysova, 2000; Marchenko, 2008; Emelyanov, 1980; Donskaia, 2003), the issue of the cultural core of this phenomenon still gives rise to several opinions.

In her article "Scientific Versions of the Concept of Literature of the Small-Numbered Indigenous Peoples of the North of West Siberia", O.K. Lagunova (Lagunova, 2011) provides the following classification of the research platforms which still remains up to date.

The concept of the European model-based accelerated development (Tsymbalistenko, 2003; Ogryzko, 1998) regards creative activity of the indigenous peoples with compliance to the logic of European literature development, which started from mythology, folklore, heroic epos, went through the stages of Humanism, Classicism, Baroque, Enlightenment, Romanticism, Realism to Modernism and Post-Modernism, despite the fact that the same process took the indigenous peoples approximately one hundred years.

The colonial challenge concept (Burkov, 2012; Vashchenko, 2002) presents literary activities as a result of influence made by social and economic processes on the North, Siberia and the Far East. According to this approach, literature makes a fruitless attempt to get over the fatal consequences of the Soviet system, which shut the small-numbered peoples out from their unique culture and positive future forever.

Colonial adaptation concept (Kudashkin, 2012; Litovskaia, 2005) regards creative activities of the indigenous peoples as a result of protecting friend from foe, their attempt to preserve the uniqueness of their culture through literature and thereby to save it from adaptation to the dominating ethnos.
Mythoutopic compensation concept (Samson, 2002) establishes the mythological and religious ground for the creativity of the indigenous peoples, claiming that, having lost their native language and traditional lifestyle due to interaction with the Soviet culture, they are striving to reproduce their lost world with the help of literary characters.

Forced experience concept (Danilina, 2000; Danilina, 1997) suggests looking at the literary activity of the indigenous people who create their works in Russian language as at experience of mastering a foreign language, experience of a foreign lifestyle imposed by circumstance, not selected at their own will.

The point of view polemically opposed to the above is the initiated artist concept (Lagunova, 2011), which claims that the masters from the indigenous peoples of the North, Siberia and the Far East feel belonging to the chosen ones (shamans), addressing the spirits of their people through creative writing, using literary practice as a shaman ritual or a song of an ancient storyteller.

The constructivist logic of the present research is based on the initiated artist concept, which regards literary activity as a practice of creating an indigenous people's ethnic identity through its chosen representatives and the fruit of their specific cultural activity.

\section{Methods}

Methodological base for the present research is the constructivist approach principle, according to which any kind of creative work of an ethnos or a people is one of the possible ways to construct the ethnocultural identity of such ethnos or people (Bart, 2006; Malakhov, 2001; Reznikova, 2012).

Moreover, the article uses results of the research carried out by the Department of Culturology of Siberian Federal University within the framework of multiple grant projects 
and field studies in the North and the Krasnoyarsk Territory (Krai) where the indigenous peoples reside (Koptseva, 2014; Kolesnik, 2014; Koptseva, 2013).

\section{Development stages and peculiarities of prose of the indigenous peoples}

Genesis of written literary activity of the indigenous peoples of Siberia and the Far East is traditionally associated with the recovery of social and political life of Russia at the turn of the $19^{\text {th }}-\mathbf{2 0}^{\text {th }}$ centuries. According to the researchers, it was mainly caused by the activities of the exiled Decembrists, revolutionaries and Bolsheviks. Their studies of the history, lifestyle, language and folklore of the indigenous peoples together with their enlightenment work caused the growth of self-consciousness of the peoples of Siberia, the North and the Far East, boosted the creation of the first written works of literature.

Development of professional literature activity of the indigenous peoples was mainly determined by publishing of the local folklore pieces collected by Russian researchers in the late $19^{\text {th }}$ century. It would be fair to say that local folklore formed the base for the written literature of the indigenous peoples.

Another important factor in the development of written literary activity is the rapid increase in the literacy rate, which began in the years of the revolution due to the efforts of the exiled, and, later, thanks to the Bolsheviks' methodical work on public education.

Written in Russian, the majority of the first prose works were slice-of-life pieces, and naturalistic sketches, developed into short stories and novels. Researchers refer to the preRevolution literature style as to educational realism and critical realism, being result of the influence of classic Russian literature.
Therefore, genesis of the indigenous peoples' literature is connected with the researchers' interest for the folklore of the peoples, and is closely intertwined with the poetic element of literature, which resonates with the folklore principium, and, therefore, with a more natural sort of literary activity.

In the said period the distinctive features of prose are: concentration on the pressing issues of the people's life; realistic-educational and realistic-critical character; interaction with the classic Russian literary tradition; domination of Russian language.

Period of the 1920-1930-s is marked with the problems of the establishment of Socialist Realism style as a whole. In those times, the majority of writers from the indigenous peoples' environment were members of literary circles and associations based at education institutions, youth organizations and cultural establishments. Of huge importance for the development of the Soviet literature of the indigenous peoples were such press bodies as newspapers, magazines, almanacs. Mass media brought writers together and gave them the tools for expressing their ideas and opinions.

It is the time of search and discussion of the writers' attitude to national folklore traditions. It is the time when the two opposite points of view on the issue were formed: 1) necessity to refine the literature of the "survival of times past", to isolate it in pure contemporariness and develop new means of expression to describe the new Soviet epoch (the "Molodoy Bolshevik" newspaper); 2) inherence of the artistic traditions of the past as the base for the national originality of the indigenous peoples' literature, creative use of folklore traditions for the depiction and solution of modern problems Due to the all-national policy of the USSR, the latter point of view gradually came to dominate. 
Prose of the period is distinctive for its Soviet themes, renewal of language due to the use of terms and concepts of the Soviet period, and development of the new Soviet protagonist, the Creator Hero. Large pieces of all possible genres are created. The themes of the works are: revolution, civil war, reorganization of life.

As remarked by modern researchers, Soviet period prose was stylistically assorted in the indigenous peoples' environment. Along with the domination of realism, there was a strong romanticist trend manifested in the use of reprocessed folklore images and techniques: glorification of some images, fixed collocations, poetic speech of the characters etc.

According to the researchers, literature of some indigenous peoples had already reached some success by the pre-war years, such as Yakut and Khanty literatures. The range of themes and genres expanded, the writers' skills improved. Those were the years of development of the standard literary languages of the Yakuts and Evenki.

During the war prose gave way to poetry as a more mobile type of literature with a strong potential for impact and appeal. Small forms of prose, such as notes, sketches, articles, short stories, prop plays etc. are actively developing. The themes and images of the Soviet time are replaced with the theme of fair war, national solidarity, patriotic uplift and national folklore images. The lyrical and epic character of literature changes for the dramatic plots, dynamic style, intensity of the described images and events.

A special place in the wartime prose is occupied by the image of V.I. Lenin, the Friendship of Peoples, dedication to the interests of the country, heroism of a Soviet man and simple everyday life. Such literature was intended to support the confidence of the people in life, in victory, to accumulate the energy and power of the people. In the wartime, romanticist and realistic lines of literature are intertwined closely as ever, sometimes being independent from each other in works by different authors, and sometimes completing each other as elements of the single whole, bringing their authors to the problems of general human values.

Period of the 1950-60-s is another time of frequent use of the Soviet themes and development of the image and character of the Soviet national hero. An important peculiarity of this stage of literature development is its expansion beyond the boundaries of their residence. It is the time of regular translation of the ethnic pieces into Russian language, of the mutual influence of Russian and ethnic literatures. It is the time when large prose genres (novels, poems) began their development. The themes of prose of the indigenous peoples change from the dominant military theme to the ordinary everyday life of the Soviet people.

One of the major themes of the post-war time is the past war and the memory of its heroes. This is when the first large pieces about struggle for peace, heroic work of the nation for the restoration and further development of the economy were written.

The post-war period is also remembered for some repressive measures taken against some writers, who came from the indigenous peoples' environment. For example, in 1943 and 1952 Resolution of the Yakut Oblast Committee of the Communist Party of the Soviet Union pronounced works by A. Kulakovsky, A. Sofronov, N. Neustroev "bourgeois-nationalistic, regressive", and the writers themselves "ideologists of bourgeoisie and nationalism" (Writers of Olonkho Land).

The period of the 1970-80-s is the period of blossom of Yakut, Khanty, Mansi, Nenets, and Evenki prose. One of the milestones of those times is the novel "Heart Beats" by an outstanding master of prose, a large artist of literature and 
social activist, Sofron Danilov. This piece is dedicated to the contemporary times, which is a distinctive feature of Yakut prose as a whole.

The prose of the 1970-80-s is significant with its deep psychological portraits of characters, analyticity, generalization of some certain events and phenomena of the contemporary time, expansion to the general human values and relying on the achievements of science. All these traits lead to the expansion and transformation of the prose genres, which get enriched with the experience of interaction with other ethnic literatures, as well as with the classic heritage of Russian and foreign prose. The only thing that remains unchanged is the combination of Realism and Romanticism. The use of folklore images is not so clear, but manifests itself in the inner structure of pieces and characters.

The 1990-s are the time of saturation of the indigenous peoples' literature with the experience of the foreign $20^{\text {th }}$ century's literature. Modern and Post-Modern literature techniques are developed. The dominating themes of prose are the inner psychological experience of the characters, total ambience of strife and instability of the situation, insight into the place and role of the indigenous peoples in the history of the Russian state and the world as a whole. It is the time of maximum expansion of artistic techniques, genre principles, development of the writers' individual styles and prose genres, who frequently turn to poetic forms and techniques.

In the early $21^{\text {st }}$ century the prose of the indigenous peoples is a multifaceted, multileveled phenomenon, the techniques and stylistics of which resonate with the Post-Modern aesthetics, which have already integrated into the global literary space.

One of the main themes of the modern prose is the interaction between the ethnic and universally human elements. Relying on the oral folk art and other literatures' traditions, depicting the deep national issues, the modern writers refer to universal human problems.

Some folklore traditions reveal themselves in the modern prose through the portraits and psychological descriptions of the characters, through the use of comparisons, metaphors and other expressive tools, through the emotional, intonation pattern of the piece, description of nature etc.

One of the key peculiarities of modern literature of the indigenous peoples of the North, Siberia and the Far East is the development of several lines of ethnic literature within one nation. For instance, besides its own tradition, Yakut prose also develops Russian, Yukagir, Even and Evenki literatures currently regarded as relatively independent flows formed in the processes of interaction and mutual influence. The dominating genres of the Northern peoples' literatures are novels and novellas. Prose develops in the stream of the artistic search for multinational literature.

The creative work of Russian-speaking writes still carries a lot of significance for the contemporary prose of the indigenous peoples. Polyphony, pluralism of cultural voices and languages, methods, styles, philosophic methods, combination of various artistic practices predominate in Russian literature. The PostModernist aesthetics and writing techniques are also frequently used. Often in the works of modern writers from the indigenous peoples we find strong interaction between different elements of the genre system, transformation and hybridization of the genres giving rise to new original genre forms.

Thus, the development of the prose of indigenous peoples is a stage-by-stage process of making up a realistic style, which originated on the ground of folklore traditions, developed and transformed in the process of adoption of the classic Russian literary heritage, determined by the involvement of artistic activities of the 
indigenous peoples into the common cultural space of Soviet, and, later, Russian reality. National traditions in prose also get transformed, moving from immediate use of stylistics, images, themes, plots and figures of speech adopted from folklore to the compositional idea- and imagebased use of such motives, creatively reviewed by the author. One of the general themes of the prose is the everyday life of people in the global space context.

Modern prose of the indigenous peoples is a part of the global cultural space due to the level and diversity of artistic techniques, genre, stylistic forms and tools, individualization of the techniques and styles used by authors and reference to the global human themes through deeply personal psychological portraits of the characters. However, the main theme of the contemporary prose of the indigenous peoples is the insight into the originality of the peoples and their involvement into the united, though diverse world, through cognition of the people's ethnic soul and determination of its role in the modern global space.

\section{Development stages and peculiarities of poetry of the indigenous peoples}

Unlike prose, poetry of the indigenous peoples of the North, Siberia, and the Far East has a naturally tight connection to the folklore traditions, especially to the ethnic epos, myths, and fairy-tales, literally growing on the base of their rhythm, imagery, and figures of speech. And even though the pieces written by the first poets thematically referred to the problems of reality and could be defined as realistic, the typification and generalization of the images, poetic collocations and alliterations have always been present in their works.

Poetry of some indigenous peoples first developed predominantly in their ethnic language
(Yakuts), based on the studies of ethnic written literary language and aiding its establishment and development.

Therefore, poetry emerges and develops in a tighter contact with ethnic folklore traditions than prose, preserving and developing, first of all, the ethnic images, ideas, themes, artistic principles, without isolation from the general literary process, solving the current problems of modern reality with the help of traditions and images of the ethnic past.

Period of the 1920-30-s is memorable for the emergence of bilingual poets and active adoption of the classic poetic techniques of Russian poets in the process of development of socialistic methods in literature as a whole.

The major theme for the poetry of those times was the theme of tightly intertwined revolution and civil war. A new and a distinctive feature of such pieces is demonstration of heroes who came from the workpeople, the ideal of a new person who gained freedom for the first time and fights for it against the old world.

The 1940-s were the time of domination of poetry in the literature of the indigenous peoples, as poetry was the basic tool of propaganda, patriotic uplift, artistic insight and reproduction of military events.

Wartime poetry had a tight contact with the people, associated with activeness, patriotism, and humanism, expressed in the bright images of the folklore heritage.

The theme of the Great Patriotic War and public consciousness, pathos and realism of descriptions specific to it are conveyed through the protagonist. The military topic is enriched with satiric poetry cycles. It is the time of turning to some other folklore forms, such as blessing and riddles. Alliteration is used not only as a way of rhythmic organization, but also as a main principle of a poetic cycle arrangement. 
The period of the 1950-60-s is the time of active adoption of some classic traditions of Russian (sonnet) and foreign (sonnet, haiku, tanka, ruba'i, ghazal) poetry.

When well-defined forms of poetry began to enter the poetry of the indigenous peoples, the poets did not strictly hold on to the compositional rules and patterns of verses, but retained the specific, original spirit of the form as a phenomenon of art. The themes of well-defined forms of ethnic poetry intend to present the diversity of the world and the artistic world outlook.

The 1970-80-s were remarked with the dominance of prose in the literature of the indigenous peoples; poetry developed under the influence of prose, enriching the image of the protagonist and rising to a new level of philosophic insight into reality.

In these years, poetry turned to the theme of industrial development of Siberia and the North: Vilyuy Dam, Baikal-Amur Mainline, AmurYakutsk Mainline etc. Descriptiveness of poetry gives way to analyticity; the diversity of poetry expands to epic and lyric-epic poems, ballads, odes, elegies, sonnets, lyric poems and songs.

The period of the 1990-s is characterized with the emergence of new styles and prosodic patterns with the simultaneous preservation of the ethnic poetic specificity manifested in the original imagery, rhythm, cyclicity, ideological broadness of literary activity. There appear lots of Russian-speaking poets who established the ultimate quality of the ethnic literature and culture as a whole.

The principle of extraction of a generalized presentation-image or experience-image with the major role of lyricism and psychologism begins to dominate. Inclination to the poetry of oral folklore, transformation and modification of the folklore genres is enhanced.

Lyric poetry of the 1990-s is generally described with the motives of anxiety, non- confidence in the future, contemplation on the evanescence of human life, the purpose of life; many vital principles are revalued.

The ideological and thematic aspect of the poetry of the indigenous peoples of the early $21^{\text {st }}$ century reflects all current political and economic changes. The lyric "self" of the poet, his civic stance are enhanced, his individuality, which was sometimes vague in the pieces expressing the general opinion of the Soviet nation, becomes more vivid. In civic lyric poetry the theme of patriotism, of man and his duty to the country and the nation, manifested in philosophic generalizations, new images and details, comes to the fore. The image of the immense Motherland becomes more limited, transformed into the "chamber" image of lesser Motherland. A current problem of civic poetry is the image of the indigenous peoples threatened with extinction in this "chaotic" time.

Another important ideological and thematic trend in modern poetry of the indigenous peoples is landscape poetry, which bears a deep ethnic character. A landscape is used not only to describe the appearance of nature, but also to reveal its life, the thoughts and feelings touching one's soul, the historical and modern images of the Motherland. The dominating type of landscape in modern poetry is a perfect landscape, where the author admires the beauty of nature.

Creative search for the genre and compositional structure of poetry concentrates around three main trends: first of all, it is the appeal to the traditional folklore genre system; secondly, it is the influence of classic European poetry; thirdly, it is poetic stylization of some Oriental genres. Modern poets attempt to revive folkloric genres in the sphere of literature, to enrich the modern genre system with the forms and techniques of the world literature.

Therefore, development of poetry of the indigenous peoples in the $20^{\text {th }}$ century is a 
sophisticated process based on national folklore traditions, enriched and developed in the process of adoption of classic Russian and foreign poetic traditions, as well as historical and cultural genesis of the indigenous peoples as a part of the Soviet, and, later, Russian state.

In general, artistic techniques, stylistic peculiarities and Post-Modernist outlook of both poetry and prose of the modern indigenous peoples develop as a natural part of the global cultural space. However, poetry demonstrates bright ethnic traits, such as visual thinking which manifests itself, first of all, in the vocabulary, in the author's metaphors and comparisons, succinct and aphoristic language; ethnic world outlook is found, first of all, in the vocabulary, author's metaphors and comparisons, succinct and aphoristic language, ethnic world outlook revealed in invoking the universal philosophic issues, traditional use of strophic alliteration, rhythmic and syntactic parallelism; cyclicity of poetry etc.

At the moment poetry is going through a turning point, searching for new ways in developing new spiritual world outlook of the indigenous peoples based on the deep ethnic traditions of the people's past.

\section{Conclusion}

As phenomena, developing simultaneously with the ethnic self-consciousness of the indigenous peoples and being one of the main tools for education and appeal to the national consciousness, prose and poetry of the indigenous peoples of the North, Siberia and the Far East do possess some ethnos-forming and ethnosconstructing qualities.

First of all, a part of development of the prose of the indigenous peoples of the North, Siberia and the Far East happened in bilingual environment, which brought the authors to the insight into the specificity of their native language, and, therefore, of the mentality of the people keeping and bearing the language. It was development of written literary activity, which aided the development and preservation of the written standard language of many indigenous peoples as one of the basic elements of the ethnic core. Prosaic works of the writers from the indigenous people preserving their ethnic language are real monuments to the ethnic character, conserving the figures of speech, collocations, and images in the speech of characters and the narration itself, preserving them for the future generations of readers.

At the same time, the poetry of the indigenous peoples is utterly and completely based on folklore traditions, especially heroic epos, myths, and fairy-tales, preserving and actualizing the traditional forms of creativity, themes and images in a new way. This way, poetry does not only embody peoples' myths in the written form, conserving ethnic traditions for the future generations, but also merges with the real life of their reader and listener, comparing real plots and characters with the mythological ones. Easily and expressively, poetry compares our everyday life to the heroic imagery of the myth, continuing and strengthening the traditional visual thinking of the ethnos.

Secondly, the prose of the indigenous peoples of the North, Siberia and the Far East has always been distinguished for the lively and realistic interest for the everyday life of the people in its historical development, literally writing chronicles of the ethnos' life in the $20^{\text {th }}$ century with a continuous reference to its past, myths and folklore images of the nation. Such historical slice-of-life approach is a specific form of describing and poeticizing of the ethnic lifestyle, writing separate day-to-day stories and events into the general canvas of the poetic chronicles of the ethnos. It forms the idea of the unified historical and cultural development of the ethnos 
in the readers' consciousness, which simplifies the problem of ethnic and national identity.

One of the main qualities of poetry is its direct reference to the folklore forms of spells, songs etc., i.e. the oral folklore of the people which used to be a part of their everyday life. Poetry, thereby, preserves the memory of the previous life experience and actualizes cult practices of the past at some certain moments of the people's development (for example, in the times of the Great Patriotic War).

Thirdly, due to its continuous contacts with the literatures of other peoples and its openness at the turn of the $20^{\text {th }}-21^{\text {st }}$ centuries, the prose of the indigenous peoples of the North, Siberia and the Far East develops the idea of involvement of a certain ethnos into global processes. It is especially important, that notwithstanding its openness to the global tendencies, the prose of the indigenous peoples retains its ethnic core, which manifests itself, first of all, in the specific world outlook, tight connection to nature and ethnic folklore images. It builds a clear understanding of originality of the ethnos and the place it occupies in the universal space.

Poetry demonstrates the openness of the peoples to the phenomena of other cultures, turning to the classic and contemporary Russian and foreign poetic experience, similarly to prose, but to a greater extent. The principal feature of this is the preservation of national traditions as a base for adoption and creative interpretation of alien artistic forms and techniques. It should be noted, that poetry retains traditional ethnic traits on the levels of vocabulary, composition, rhythmic, ideology and theme, which means a lot of opportunities of meeting national traditions through reading/listening to other poetries.
Fourthly, as a specific type of literature, prose has a strong educational capacity, able to reveal sophisticated psychological experience, describe collisions of plots, changes in destinies and characters of the protagonists, demonstrating the vivacity of a certain ethnos as a developing, deep, multifaceted one, having the capacity for change, preserving its deep ethnic core. Perhaps, this quality is the most important one for the preservation of the ethnic core in the current global processes, as only a living being able to develop may survive.

Unlike prose, poetry possesses the capacity to create succinct and bright metaphoric images, specific rhythmic arrangement of text, and, therefore, high suggestive influence on the reader/ listener, plunging them into the atmosphere of listening to an ethnic epos, a myth or a fairy-tale, as poetry of the indigenous peoples often retains its folkloric rhythm, imagery and arrangement of verses. The listener may imagine being in a typical for the ethnos situation of listening to a storyteller, which forms the deep personal emotional affection for the ethnic symbols and traditions.

Fifthly, due to its diversity and profusion, poetry of the indigenous peoples may find its approach to any reader; we should keep in mind that today it is frequently written simultaneously in the ethnic and Russian languages. That is why poetry reflected such modern cultural phenomena as pluralism of opinions on the world order, gender differences in literature, specifically individual perception of events and phenomena, deep psychologism to a greater extent; for this reason, poetry has a greater capacity to aid development of the ethnic and national identity of the indigenous peoples in the Post-Modern reality.

\section{References}

Allen, C. (2002). Blood narrative: Indigenous identity in American Indian and Maori literary and activist texts / C. Allen. Duke University Press. 
Driskill, Q. L. (Ed.). (2011). Queer Indigenous studies: Critical interventions in theory, politics, and literature / Q.L. Driskill. University of Arizona Press.

Heiss, A. (2003) Dhuuluu-Yala: To Talk Straight-Publishing Indigenous Literature / A. Heiss. Aboriginal Studies Press.

Heiss, A. (2014) Macquarie PEN anthology of Aboriginal literature / A. Heiss, P. Minter. Allen \& Unwin.

Knudsen, E.R. (2004). The Circle and the Spiral: a study of Australian aboriginal and New Zealand Maori literature / E.R. Knudsen. Rodopi, 68.

Koptseva, N.P., Kirko. V.I. (2014). Specificity of ethnogeny indigenous peoples by Central Siberia in the transition from the traditional type of society to modern society. Life Sci J;11(7), 409-413.

Shoemaker, A. (2004). Black words, white page: Aboriginal literature 1929-1988 / A. Shoemaker. ANU E Press.

Bart, F. (2006) Etnicheskie gruppy i sotsial'nye granitsy. Sotsial'naia organizatsiia kul'turnykh razlichiy: sbornik statey [Ethnic Groups and Social Boundaries. Social Organization of Cultural Differences: Collection of Articles], $200 \mathrm{p}$.

Bakhteeva, L.I. (2008) Izuchenie diamiki kul'tury korennykh narodov Severa v kontekste globalizatsii [Studying the Dynamics of Culture of the Indigenous Peoples of the North in the Globalization Context], In Vestnik Cheliabinskoy gosudarstvennoy akademii kul'tury i iskusstv [Newsletter of Chelyabinsk State Academy of Culture and Arts], 1 (13), 1 - 10.

Burkov, L.N. (2012) Rol' perevodnykh proizvedeniy v razvitii mariyskoy literatury nachala XX $v e k a$ [Role of Translated Works in the Development of Mariy Literature of the Early $20^{\text {th }}$ Century], In Vestnik Chuvashskogo universiteta [Chuvash University Newsletter], (4).

Vashchenko, A.V. (2002) My - vasha sovest'. Ispovedimye puti rodstva: khantyyskaia literatura v svete literatur "korennykh amerikantsev" [We Are Your Consciousness. The Scrutable Ways of Genes: Khanty Literature in the Context of the "Ethnic American" Literatures], In Khantyyskaia literatura [Khanty Literature], $284-293$.

Danilina, G.I. (1997) Mif i literatura v proze pisateley Tiumenskogo Severa [Myth and Literature in the Prose of the Writers of the Tyumen North], In Literatura Tiumenskogo kraia [Tyumen Territory Literature], $121-163$.

Danilina, G.I. (2000) Pisatel' i ego kray: ontologicheskiy koflikt kak nauchnaia problema [Writer and His Territory: Ontological Conflict as a Problem of Science] / G.I. Danilina, N.E. Erter, In Filologicheskiy diskurs [Philological Discourse], 1, 27 - 36.

Donskaia, T.K. (2003) Tema rodnoy zemli v tvorchestve severnykh pisateley [Theme of the Native Land in the Works of Northern Writers], In Literatura narodov Severa [Literature of the Northern People], 2, $11-20$.

Emel'ianov, E.V. (1989) Siuzhety iakutskikh olonkho [Yakut Olonkho Stories], 305 p.

Zamaraeva, Iu.S. (2015) Global'nye transformatsii, kotorye perezhivaiut indigennye narody Severa [Global Transformations the Indigenous Peoples of the North Are Going Through], In Sovremennye problemy nauki i obrazovaniia [Contemporary Problems of Science and Education], $1-1,1882$.

Kalenchuk, E.A. (2015) Istoriia izucheniia literaturnogo fol'klora u korennykh i malochislennykh narodov Severa, Sibiri i Dal'nego Vostoka [History of Researching Literary Folklore of the Indigenous 
and Small-Numbered Peoples of the North, Siberia and the Far East] / E.A. Kalenchuk, A.R. Banshchikova, In History [Istoriia], $62-66$.

Kolesnik, M.A. (2014) Obzor izucheniia fol'klora korennykh narodov Severa [Review of the Indigenous Peoples of the North Folklore Studies]. Litera, 3, 9 - 11.

Koptseva, N.P. (2013) Formirovanie etnicheskoy kul'turnoy identichnosti v sovremennoy Rossii s pomoshch'iu proizvedeniy natsional'nogo iskusstva (na primere evenkiyskogo eposa i dekorativnoprikladnogo iskusstva) [Forming Ethnic Cultural Identity of Modern Russia with the Pieces of Ethnic Art (Based on Evenki Epos and Applied and Decorative Arts] / N.P. Koptseva, N.N. Nevol'ko, K.V. Reznikova, In Pedagogika iskusstva [Pedagogy of Art], 1, 1 - 15.

Koptseva, N.P. (2014) K voprosu o gosudarstvennoy politike v oblasti sokhraneniia iazykov korennykh malochislennykh narodov Severa [To the Issue of State Policy for the Preservation of Languages of the Small-Numbered Indigenous Peoples of the North], In Arktika i Sever [Arctic and the North], (16), 34.

Koptseva, N.P. (2014) Vliianie sovremennykh kul'turnykh praktik na etnicheskuiu identichnost' korennykh malochislennykh narodov Tsentral'noy Sibiri [Influence of Modern Cultural Practices on the Ethnic Identity of Small-Numbered Indigenous Peoples of the Central Siberia], In NB. Problemy politiki i obshchestva [NB. Problems of Politics and Society], 6, 1 -27. DOI: 10.7256/2306-0158.2014.6.12201. URL: http://e-notabene.ru/pr/article_12201.html

Koptseva, N.P., Seredkina, N.N. (2013) Konstruirovanie pozitivnoy etnicheskoy identichnosti v polikul'turnoy sisteme [Construction of Positive Ethnic Identity in a Polycultural System]. Krasnoyarsk, Siberian Federal University.

Kudashkin, V.A. (2012) Protsess akkul'turatsii u korennykh malochislennykh narodov Vostochnoy Sibiri v usloviiakh sovetskoy sistemy v 1920-1980-e gg. [Process of Acculturation of the SmallNumbered Indigenous Peoples of the East Siberia in the Soviet System Conditions in the 1920-1980-s], In Istoricheskie, filosofskie, politicheskie i iuridicheskie nauki, kul'turologiia i iskusstvovedenie. Voprosy teorii i praktiki [Historical, Philosophic, Political, Legal Sciences, Culture Studies and Art Criticism. Theoretical and Practical Issues], 3-2, 102-105.

Lagunova, O.K. (2007) Fenomen tvorchestva russkoiazychnykh pisateley nentsev i khantov posledney treti XX veka: E. Aypin, Iu. Vella, A. Nerkagi [Creativity Phenomenon of the Russian Speaking Nenets and Khanty Writers of the Late $20^{\text {th }}$ Century: E. Aypin, Iu. Vella, A. Nerkagi].

Lagunova, O.K. (2011) Nauchnye versii literaturnogo tvorchestva korennykh malochislennykh narodov Severa Zapadnoy Sibiri [Scientific Versions of Literary Activities of the Small-Numbered Indigenous Peoples of the North of the West Siberia Region], In Vestnik Tiumenskogo gosudarstvennogo universiteta [Tyumen State University Newsletter], 1, 60 - 68.

Libakova, N.M., Sertakova, E.A., Kolesnik, M.A., Sitnikova, A.A., Il’beykina, M.I. (2016) Sovremennye strategii sotsial'nogo pozitsionirovaniia sibirskikh regionov [Modern Strategies of the Social Positioning of Siberian Regions], In Sotsiodinamika [Sociodynamics], 1. 162 - 189. DOI: 10.7256/2409-7144.2016.1.17420. URL: http://e-notabene.ru/pr/article_17420.html

Libakova, N.M. (2015) Upravlenie zdravookhraneniem dlia korennykh narodov Tsentral'noy Sibiri (na materiale analiza Krasnoiarskogo kraia) [Public Health Management for the Indigenous Peoples of the Central Siberia (Based on the Analysis Made for the Krasnoyarsk Territory (Krai)), In Trendy $i$ upravlenie [Trends and Management], 4, 380 - 394. DOI: 10.7256/2307-9118.2015.4.16854

$$
-1942-
$$


Litovskaia, M.A. (2005) Kolonial'naia problematika v tvorchetve Tat'iany Moldanovoy [Colonial Problem in the Works by Tatiana Moldanova], In Kosmos Severa [Cosmos of the North], 4, 79 - 92.

Lopulenko, N.A. (2002) Korennye malochislennye narody rossiyskogo Severa: vstupaia v XXI vek [Small-Numbered Indigenous Peoples of the Russian North: Entering the $21^{\text {st }}$ Century], In Rossiia i sovremennyy mir [Russia and the Modern World], 4 (37), 57 - 74.

Malakhov, V.S. (2001) Iazyk i etnicheskiy konflikt [Language and Ethnic Conflict]

Marchenko, O.N. (2008) Natsional'no-regional'nyy komponent $v$ kurse literatury (na primere izucheniia fol'klora korennykh narodov Taymyra) [Ethnic and Regional Components in the Literature Course (Based on the Taymyr Indigenous Peoples' Folklore Studies)], In Sibirskiy pedagogichekiy zhurnal [Siberian Pedagogical Journal], (2).

Nemysova, E.A. (2000) O razvitti etnicheskogo soznaniia obsko-ugorskikh narodov: rol' literatury $i$ shkoly [On the Development of the Ethnic Consciousness of Ob-Ugrian Peoples: Role of Literature and School], In Severnyy region: Nauka. Obrazovanie. Kul'tura [Science. Education. Culture], 2, $113-117$.

Ogryzko, V.V. (1998) Pisateli i literatory malochislennykh narodov Severa i Dal'nego Vostoka: Bibliograficheskiy spravochnik [Writers and Literature Activists of the Small-Numbered Peoples of the North and the Far East: Bibliographic Reference Book], Part 1, 536 p.

Pisateli Zemli Olonkho: Bibliograf.spravochnik [Writers of the Olonkho Land: Bibliographic Reference Book], compiled by D.V. Kirillin, V.N. Pavlova, D. Shevkov. Accessed at: http://www.nlib. sakha.ru/resoures/data/Inquirys/Writer/index.htm

Popov, Iu.I. (2001) Literatura Iamala XX veka: sbornik literaturno-kriticheskikh statey. IamaloNenetskiy okruzhnoy in-t usovershenstvovaniia uchiteley [Yamal Literature of the $20^{\text {th }}$ Century: Collection of Articles on Literary Criticism. Yamal-Nenets Okrug Institute of Teachers' Professional Improvement].

Poshataeva, A.V. (1988) Literatury narodov Severa [Literatures of the Northern Peoples], 125 p.

Razumovskaia, V.A. (2012) Semantika khudozhestvennogo obraza v perevode i originale: kot Begemot [Word Picture Semantics in the Original and the Translated Texts: Behemoth the Cat], In Problemy istorii, filologii, kul'tury [Problems of History, Philology, Culture], 3, 268.

Razumovskaia, V.A. (2014) Kul'turnaia informatsiia: adaptatsiia $i$ otstranenie v perevode [Cultural Information: Adaptation and Alienation in Translation], In Professional'no-orientirovannoe obuchenie inostrannym iazykam [Profession-Oriented Foreign Language Teaching], 8, 125-129.

Reznikova, K.V. (2014) K voprosu ob utochnenii poniatiy "etnos" $i$ "etnichnost", [To the Issue of the "Ethnos" and "Ethnicity" Terms' Definition], In Sotsiodinamika [Sociodynamics], 12, 90-102. DOI: 10.7256/2409-7144.2014.12.13913. URL: http://e-notabene.ru/pr/article_13913.html

Reznikova, K.V. (2016) K voprosu ob epicheskom kul'turnom nasledii korennykh malochislennykh narodov Krasnoiarskogo kraia [To the Issue of Epic Cultural Heritage of the Small-Numbered Indigenous Peoples of the Krasnoyarsk Territory (Krai)]. Litera, 2, 20-34. DOI: 10.7256/24098698.2016.2.18917. URL: http://e-notabene.ru/fil/article_18917.html

Rogacheva, N.A. (2003) Ia veriu v muzyku stikha [In Music of Poetry I Trust], In Mansiyskaia literatura [Mansi Literature], 306-314.

Samson, D. (2002) Neveroiatnost' Trekh Mirov [Impossibility of the Three Worlds], In Khantyyskaia literatura [Khanty Literature], 171 - 178. 
Sangi, V.M. (1989) Antologiia fol'klora narodnostey Sibiri, Severa i Dal'nego Vostoka [Anthology of the Siberian, Northern and Far Eastern Peoples' Folklore], 471 p.

Semenova, V.G. (2011) Mifologicheskie vozzreniia naroda Sakha v tvorchestve Alampa [Mythological Worldview of the Sakha People in Alampa Works], In Vestnik Severo-Vostochnogo federal'nogo universiteta im. M.K. Ammosova [M.K. Ammosov North-East Federal University Newsletter], 8(2).

Sertakova, E.A. (2013). Sotsial'nyy konstruktivizm kak kontseptsiia konstruirovaniia etnosa [Social Constructivism as an Ethnos Construction Concept], In Sovremennye problemy nauki $i$ obrazovaniia [Modern Problems of Science and Education], 6, 999.

Sitnikova, A.A. (2015). Korennoe obrazovanie: aktual'noe sostoianie i problemy [Indigenous Education: Current Condition and Problems], In Pedagogika i prosveshchenie [Pedagogics and Education], 3, 300 - 311. DOI: 10.7256/2306-434X.2015.3.17048.

Tsymbalistenko, N.V.(2003) Sever est' Sever... Istoricheskie sud' by narodov Iamala v literaturnom osveshchenii [North is North... Historical fates of the Yamal Peoples Described by Literature], 172 p.

\title{
История и специфика \\ литературного творчества \\ коренных народов
}

\author{
А.В. Кистова, Н.Н. Пименова \\ Сибирский федеральный университет \\ Россия, 660041, Красноярск, пр. Свободный, 79
}

В статье представлен обзор основных этапов развития литературного творчества коренных народов Севера, Сибири и Дальнего Востока. Рассмотрены ключевые особенности литературы коренных народов. Выявлена специфика прозы и поэтического творчества. Обозначено несколько различных научных точек зрения на сущность и характер творчества коренных народов как на этнокультурное явление.

Сделаны выводы об этноформирующих качествах литературного творчества коренных народов, которое можно рассматривать как один из эффективных способов конструирования этнокультурной и национальной идентичности в современном мире.

Ключевые слова: литература, проза, поэзия, коренные народы, Север, Сибирь, Дальний Восток.

Статья написана при выполнении исследований по гранту Красноярского краевого фонда поддержки научной и научно-технической деятельности на тему: "Создание корпуса текстов для детей на родных языках (эвенкийский, ненеикий, нганасанский, долганский) как способ сохранения уникального культурного наследия коренных малочисленных народов Красноярского края».

Научная специальность: 24.00.01 - теория и история культуры. 